\title{
Green Tea Compound in Chemoprevention of Cervical Cancer
}

\author{
Changping Zou, PhD ${ }^{\star}, \dagger$, Huaguang Liu, PhD*, Jean M. Feugang, PhD $\dagger, \ddagger$, Zhengping Hao, \\ $\mathrm{PhD}^{\dagger}, \mathrm{H}-\mathrm{H}$ Sherry Chow, $\mathrm{PhD}^{\dagger}$, and Francisco Garcia, MD, MPH ${ }^{\dagger, \S}$ \\ *Guangxi Medical University, Nanning City, China \\ †Arizona Cancer Center, The University of Arizona, Tuczon, AZ \\ FDepartment of Animal and Dairy Sciences, Mississippi State University, Mississippi State, MS \\ $\S$ The University of Arizona National Center of Excellence in Women's Health, Tuczon, AZ
}

\section{Introduction}

Cervical cancer is the second leading cause of cancer deaths in women worldwide with 500,000 new diagnoses annually, most occurring in the developing world (1). In the United States there were approximately 9,710 new diagnoses and nearly 3,700 deaths in 2006 (2). Although the 5-year survival rate of cervical cancer in the US and Western Europe ranges from 70 to $65 \%$, for the rest of the world rates are significantly lower $(40 \%$,) reflecting the disproportionate burden of the disease in developing countries (3). Despite a relatively low incidence and improved 5-year survival rates for the of cervical cancer for the US in general, important disparities contribute to substantial gaps for Black, Hispanic and economically disadvantaged patients (2). Mortality rates have declined over the last decade due to the success of cytology based screening for cancer precursors in developed world settings, however even in these locations women with poor access to health care services continue to present clinically with high-grade cervical cancer precursors.

A persistent HPV infection is a prerequisite for the development of precursor lesions and invasive cervical cancer. Invasive cervical cancer has a long pre-malignant phase termed cervical intraepithelial neoplasia (CIN). The protracted course from HPV infection to CIN and invasive disease make CIN an ideal candidate for chemoprevention (4,5). During the last decade, the relationship between tea consumption and cancer has been a subject of research interest for many investigators. Recent reports have thoroughly reviewed and summarized epidemiological and experimental studies on tea and cancer prevention (6-10), especially tea compound in inhibition of cervical carcinogenesis (11-15). Experimental studies demonstrating the chemo-preventive effects of tea have been conducted primarily with green tea, given the presence of highly polymerized components in black tea, which are not well characterized.

The evidence obtained from both in vitro and in vivo studies concerning potentially protective effects of green tea or green tea components is compelling. Green tea, green tea extract, green tea polyphenols, and epigallocatechin gallate (EGCG) have been shown to inhibit carcinogenesis induced by a wide variety of carcinogens in rodent cancer models $(16,17)$. Moreover, the cancer chemopreventive activity of these compounds has been demonstrated in variety of tissues and organs such as colon, duodenum, esophagus, forestomach, large intestine, liver, lung, mammary glands, and skin (6-10).

Address correspondence and reprint requests to Francisco Garcia, MD, MPH, The University of Arizona Health Sciences Center, Tucson, AZ 85724-5078. fcisco@u.arizona.edu. 
A clinical trial using green tea compounds in subjects with persistent oncogenic HPV infection and low grade cervical disease (CIN1) is being carried out in our group (published or still unpublished study?). In preparation for this effort, we conducted a series of experiments using immortalized human cervical epithelial cell lines or pre-cancerous cell lines that mimic the CIN in vivo and carcinoma cell lines as in vitro models to explore potential mechanisms for the activity of green tea compounds and its precursors in cervical cancer. We investigated the effects of two green tea compounds, EGCG and poly E, on growth inhibition, cell cycle, and apoptosis induction in cervical cancer and pre-cancer cell lines. The results will improve our understanding of the potential role of green tea compounds in cervical cancer chemoprevention.

\section{Materials and Methods}

\section{Cell culture}

The human cervical epithelial cell line TCL1 and cervical carcinoma cell lines HeLa and Me180 were provided by Dr. Reuben Lotan (MD Anderson Cancer Center, Houston, Texas). The human cervical epithelial cell lines TCL1 were primary cells electroporated with cloned viral DNAs from HPV types 16, and 18 (18). Cervical cells were grown in monolayer culture in a 1:1 (v:v) mixture of Dulbecco's modified Eagle's Minimal Essential Medium (DMEM) and Ham's F12 medium containing 5\% fetal bovine serum (FBS) at $37^{\circ} \mathrm{C}$ in the humidified atmosphere of $5 \% \mathrm{CO}_{2}: 95 \%$ air.

\section{Green tea compounds}

EGCG was provided by Dr. Shun-Jun Cheng's laboratory (Department of Chemical Etiology and Carcinogenesis, Cancer Institute, Peking Union Medical College), and Polyphenol E (poly E) obtained from the NCI Consortium Program. Each compound was dissolved in $\mathrm{dH}_{2} \mathrm{O}$ for a final concentration of $10 \mathrm{mg} / \mathrm{ml}$, and stored in an atmosphere of $\mathrm{N}_{2}$ at $-80^{\circ} \mathrm{C}$ (for $\mathrm{EGCG}$ ) and $4^{\circ} \mathrm{C}$ (for poly $\mathrm{E}$ ).

\section{Growth inhibition assay in monolayer culture}

Exponentially growing cells (TCl-1, Me180 and HeLa) were seeded at densities ranging from 1000 to 3000 cells per well in 96-well culture plates and treated the second day with concentrations of $0,1,5,10,25$, and $50 \mu \mathrm{g} / \mathrm{ml}$ EGCG or poly E. Cell growth inhibition was determined after five days of treatment using the crystal violet method as described previously (18). Briefly, cells were fixed by $5 \%$ glutaraldehyde in phosphate-buffered saline solution (PBS), rinsed with distilled water and dried completely. Cells were incubated in a mixture (v/v) of $200 \mathrm{mM} 3$-(cyclohexylamino)-1-propanesulfonic acid (CAPS; pH 9.5) and $0.2 \%$ crystal violet at $25^{\circ} \mathrm{C}$ for $30 \mathrm{~min}$, and then washed and dried. Fixed and stained cells were rendered soluble with $10 \%$ glacial acetic acid, and the absorbance at $590 \mathrm{~nm}$ was determined using a plate reader. The percentage of growth inhibition was calculated according to the equation: inhibition $=(1-\mathrm{Nt} / \mathrm{Nc}) \times 100$, where $\mathrm{Nt}$ and $\mathrm{Nc}$ are the numbers of cells in treated and control cultures, respectively. All experiments were performed in triplicate and the mean \pm standard deviations (SD) were calculated, and tested for statistical significance $(\mathrm{p}<0.05)$.

\section{Analysis of apoptosis induced by EGCG and poly E}

TCL-1, Me180 and HeLa cells were cultured in the presence of $0,5,25$ and $50 \mu \mathrm{g} / \mathrm{ml}$ of EGCG or poly E. After 2 days of incubation, cells were collected and fixed in 1\% formaldehyde in PBS ( $\mathrm{pH}$ 7.4). The Terminal deoxynucleotidyl transferase (TdT)-mediated fluorescein-deoxyuridine-triphosphate (dUTP) nick-end labeling (TUNEL) assay from Phoenix Flow Systems (San Diego, CA) was used to detect the apoptotic cells. Fixed cells 
were washed twice with $1 \mathrm{ml}$ Wash Buffer and the pellet $\left(\sim 10^{6}\right.$ cells $)$ was re-suspended in $50 \mu 1$ staining buffer. Cells were incubated at $37^{\circ} \mathrm{C}$ for $60 \mathrm{~min}$ and stained with $500 \mu \mathrm{l}$ of propidium iodide/RNase A solution in the dark for $30 \mathrm{~min}$ at room temperature.

Cells were then analyzed using a FACScan flow cytometer (BD Biosciences, San Jose, CA) with a $15 \mathrm{~mW}$ argon laser used for excitation at $488 \mathrm{~nm}$. Fluorescence was measured at 542$585 \mathrm{~nm}$. The Phoenix flow cytometry kit included suspensions of cells that served as negative and positive controls. The Cellquest Pro computer (BD Biosciences) with ModFit LT by Verity Software was used to determine the percentage of apoptotic cells.

Cell cycle analysis by propidium iodide (PI) staining. TCl-1, Me180 and HeLa cells were cultured in the presence of 0 and $50 \mu \mathrm{g} / \mathrm{ml}$ of poly E. After 2 days of incubation, cells were harvested by trypsinization, fixed in $1 \%$ paraformaldehyde for $30 \mathrm{~min}$ on ice then washed in PBS and re-suspended in $70 \%$ ethanol containing $1 \% \mathrm{HCl}$ for $10 \mathrm{~min}$ at $-20^{\circ} \mathrm{C}$. After washing, cells were stained with $500 \mu \mathrm{l}$ of propidium iodide/RNase A solution in the dark for $30 \mathrm{~min}$ at room temperature.

Cells were analyzed using a FACScan flow cytometer (BD Biosciences, San Jose, CA) with a $15 \mathrm{~mW}$ argon laser used for excitation at $488 \mathrm{~nm}$. Fluorescence was measured at 542-585 $\mathrm{nm}$. The Cellquest Pro computer (BD Biosciences) with ModFit LT by Verity Software was used to determine the proportion of cells in $\mathrm{G}_{1}, \mathrm{~S}$, and $\mathrm{G}_{2}$ phases of the cell cycle. All experiments were performed in triplicate and the mean \pm standard deviations (SD) were calculated, and tested for statistical significance $(\mathrm{p}<0.05)$.

\section{Western blot analysis}

The cervical carcinoma Me180 cells were treated with different concentrations of EGCG $(0$, 5,25 , and $50 \mu \mathrm{g} / \mathrm{ml}$ ) for two days. Total protein was extracted and $30 \mu \mathrm{g}$ were loaded in each well. Protein was separated on $8 \%$ SDS-PAGE gel and then transferred onto nitrocellulose membranes. The membranes were blocked with 5\% nonfat dry milk followed by incubation with mouse $\mathrm{IgG}$ monoclonal antibodies against $\mathrm{p} 53$, p21, and $\mathrm{p} 27$ proteins (Santa Cruz Biotech, Santa Cruz, CA). Membranes were washed before incubating with a peroxidase-conjugated anti-mouse antibody (Amersham) and immunoreactive bands were detected using an Enhanced Chemiluminescence reagent (ECL; Amersham). After the X-ray detection of immunoreactive bands, the membranes were stripped and reused for detection of $\beta$-actin.

\section{Immunohistochemistry}

Cervical cancer cells (TCl-1 and HeLa) were treated with $50 \mu \mathrm{g} / \mathrm{ml}$ of EGCG and poly E. After two days of incubation, cells were collected and fixed on pathologic slides. Cell membranes were made soluble, followed by a $30 \mathrm{~min}$ inactivation of the endogenous peroxidase in $0.015 \%$ peroxide in methanol and a 10 min rehydration in PBS. Cells were blocked for $30 \mathrm{~min}$ with 3\% horse serum (NHS) diluted in PBS, followed by $60 \mathrm{~min}$ incubation with a mouse anti-HPV-E7 antibody. After washing, cells were incubated for another $60 \mathrm{~min}$ with a biotinylated secondary antibody against the mouse anti-HPVE7antibody. Then, slides were washed in PBS and incubated with avidin-biotin-peroxidase complex (ABC; Vector Laboratories) for $30 \mathrm{~min}$. The peroxidase reaction was developed with diaminobenzidine/peroxide and the slides were washed, counterstained with hematoxylin, mounted in Aqua-mount, and observed under a light microscope. Positive and negative controls were included for each experiment and all procedures were carried out at room temperature. 


\section{Results}

\section{Growth inhibitory effect of EGCG and poly E on human cervical cell lines}

EGCG and poly E were tested at different concentrations $(0,1,5,10,25$, and $50 \mu \mathrm{g} / \mathrm{ml})$ to compare the effect on the growth of immortalized human cervical epithelium (TCL-1) cells, and two cervical cancer cell lines (HeLa and Me180) grown in monolayer culture. Results summarized in the figure 1 demonstrate that at lower concentrations ( 1 and $5 \mu \mathrm{g} / \mathrm{ml})$, EGCG and poly $\mathrm{E}$ induced a similar level of cell growth inhibition. The average inhibition rates were about $17.7 \%$ and $37.3 \%$ in cancer cells, and $19.2 \%$ and $33.4 \%$ in TCL-1 cells after EGCG treatment, compared to $21 \%$ and $37 \%$ in cancer cells, and $25.9 \%$ and $33.8 \%$ with ploy E treatment. At high concentrations $(10,25$ and $50 \mu \mathrm{g} / \mathrm{ml})$, EGCG caused a stronger growth inhibitory effect than poly E, irrespective of the cell types: $64.6 \%, 79.26 \%$ and 92.8\% in cancer cells and 72.7\%, 96.6\%, and 94.2\% in TCL-1 cells for EGCG, and 52\%, $59.6 \%$ and $72.2 \%$ in cancer cells and $62.9 \%, 69.6 \%$ and $83.9 \%$ in TCL-1 for poly E. Mean differences between low and high-dose comparisons were significantly different. Figure 2 illustrates a representative image of the morphological changes induced by green tea compounds after 3 days of incubation, and how these changes correlate with the agents' effects on cell growth.

\section{Effects of green tea compounds on apoptosis and cell cycle}

To assess the possible mechanisms of growth inhibitory effect of EGCG and poly E, apoptosis induction and cell cycle analysis were performed. Figure 3 shows that apoptosis is induced by EGCG in a dose-dependent statistically significant manner in all cell lines (TCl-1, HeLa and Me180), whereas a slight increase was observed only at $50 \mu \tilde{\mathrm{g}} / \mathrm{ml}$ with poly E (data not shown).

The cell cycle performed with $50 \mu \mathrm{g} / \mathrm{ml}$ poly E shows an increase of cells in $\mathrm{G}_{1}$ phase and a decrease of cells in S phase. The same profile was observed with both immortalized (TCL-1) and cancer (HeLa and Me180) cells.

\section{Modulation of gene expression green tea compounds}

The effects of different concentrations of $\operatorname{EGCG~}(0,5,25$ and $50 \mu \mathrm{g} / \mathrm{ml})$ on the expression of the apoptosis-associated genes p53, p21, and p27 were examined in Me180 cells. The results show a dose-dependent increase in $\mathrm{p} 53$ and $\mathrm{p} 21$ proteins expression. The level of p27 protein expression was unchanged.

\section{Immunohistochemistry staining of HPV-E7 expression in cervical cells}

The expression of HPV-E7 was examined by immunohistochemistry in TCL1 and HeLa cells treated with 0 or $50 \mu \mathrm{g} / \mathrm{ml} \mathrm{EGCG} \mathrm{or} \mathrm{poly} \mathrm{E.} \mathrm{A} \mathrm{strong} \mathrm{positive} \mathrm{staining} \mathrm{of} \mathrm{HPV-E7}$ expression was observed in control group, whereas both EGCG and poly E treated-groups showed a decrease in HPV-E7 expression (Fig. 5).

\section{Discussion}

Cancer of the cervix is the third most common malignancy worldwide in women, and the most common gynecologic cancer in the developing world. In developed countries, prevention of cervical cancer achieved by the widespread and systematic use of cervical cytologic screening, has contributed to the successful decrease in the incidence of invasive cervical carcinomas. In the developing world, cervical cancer remains a common malignancy impacting the lives of women during their period of highest productivity. Especially in low-resource settings, an inexpensive dietary chemo-preventive intervention would be an attractive adjunct to existing cervical cancer prevention programs. 
It is well-known that the regular consumption of fruits and vegetables is highly associated with the reduced epidemiologic risk of different types of cancer (18-21) and green tea consumption is associated with lowering certain cancer incidences. This has not been demonstrated for cervical cancer specifically.

Polyphenol E (poly E) and (-)-Epigallocatechin gallate (EGCG) are one of the various polyphenols found in green tea. In this study, we investigated the chemopreventive effect of EGCG, the major component of green tea polyphenols, and poly $E$ on the growth of HPVpositive (HeLa, adenocarcinoma and Me180, squamous carcinoma) and HPV-immortalized cervical epithelial (TCL-1) cells. Results showed that EGCG and poly E inhibit the growth of both immortalized TCL-1 cells and cancer cell lines HeLa and Me180. In cancer cell lines, cell growth rate was inhibited by the high concentration of poly E and EGCG (50 $\mu \mathrm{g} /$ ml: 76.9 and 100\%) in squamous cell carcinoma cell line, Me180, whereas growth inhibition was less in adenocarcinoma cell lines, HeLa (67.5 and 85.6\%). Suggesting that growth inhibition by treatment with green tea polyphenol may be modulated by cellular type.

The EGCG-induced growth inhibition was stronger than that of poly E. Nevertheless, the effect of poly E on cell growth was observed at highest concentrations ( 25 and $50 \mu \mathrm{g} / \mathrm{ml}$ ) than that of EGCG (from $10 \mu \mathrm{g} / \mathrm{ml}$ ). Most studies focused only on EGCG which is by far, the most pharmacologically active green tea polyphenol, and our findings are consistent with previous studies reporting the beneficial effects of EGCG on different types of human cancer and cancer cell lines (lung, colon, breast, cervix, etc.) $(8,11,12,14,15,22-24)$. Our result suggests that green tea poly $\mathrm{E}$ at high concentrations may be a potential chemo preventive agent.

In this study, the concentrations of EGCG and poly E: $0 ; 1 ; 5 ; 10 ; 25$ and $50 \mu \mathrm{g} / \mathrm{ml}$, was consistent with the previous studies showing an inhibition of growth of HPV-18 immortalized cervical cells and cervical cancer cell lines $(14,15)$. The dose-dependent effects of EGCG and poly E on growth inhibition were also consistent with previous reports $(14,15)$. At present, the physiological extra- and intra-cellular levels of green tea polyphenols are unknown. Even the amount of tea ingestion necessary to obtain noticeable benefits is still under debate. It has been reported that a cup of tea contains approximately $120-150 \mathrm{mg}$ EGCG, which is equivalent to $300 \mu$ moles $(9,25)$. For a single cup of tea, Lin et al. (26) estimated a maximum of $60 \mu \mathrm{M}$ EGCG in the human blood while Lee et al. (7) measured a range of 0.2 to $0.65 \mu \mathrm{M}$ in human blood plasma after consumption of 2-3 cups of green tea. The difference between these data may be attributed to the biodegradability of the ingested tea and polyphenols and/or the delay between ingestion and EGCG measurement. Other studies have suggested amounts of about 10 cups $(27,28)$. Our data suggest that a regular and high consumption of green tea may contribute to the prevention of cervical cancer.

Several mechanisms of cancer inhibition by green tea polyphenols have been proposed. We investigated the regulation of apoptosis and cell cycle progression, which could be important targets for cancer chemoprevention $(9,29-33)$. For this purpose, experiments were run one day before the onset of the significant inhibition of cell growth, allowing a better evaluation of events occurring downstream.

The dose-dependent increase of apoptosis in immortalized and cancer cells in the presence of EGCG are in agreement with other reports on human carcinoma cells $(11,12,15,34)$. The oxidative properties of EGCG in cancer cells have been suggested to explain the increase of apoptosis $(34,35)$. Indeed, higher concentrations (100-200 $\mu \mathrm{M})$ of EGCG appear to be associated with an intracellular production of free radicals whereas low concentrations (10 $\mu \mathrm{M}$ ) have anti-oxidative properties (14,34). In the present study, $5 \mu \mathrm{g} / \mathrm{ml}$ (equivalent of 10 
$\mu \mathrm{M})$ EGCG induced a significant increase of apoptosis in both immortalized TCL-1 and squamous carcinoma Me180 cell lines, while only 25 and $50 \mu \mathrm{g} / \mathrm{ml}(50$ or $100 \mu \mathrm{M})$ EGCG induced the same significant effect with adenocarcinoma HeLa cells. These results also suggest a differential sensitivity of cervical cancer cell types to EGCG exposure. Some studies have reported an association between the induction of apoptosis and disruption or loss of telomere structure (36-38). A loss of telomerase activity has been observed in cervical adenocarcinoma cancer cells (HeLa: 13 and OMC-4/TMCC1) (39) exposed to the same range of EGCG concentrations $(50 \mu \mathrm{M}$ and/or $100 \mu \mathrm{M})$. A similar pattern in apoptosis induction was not observed with poly $\mathrm{E}$ treatment, where only a slight increase was found at $50 \mu \mathrm{g} / \mathrm{ml}$. However in a parallel experiment, we found that the concentration of $100 \mu \tilde{\mathrm{g}} / \mathrm{ml}$ poly $\mathrm{E}$ induced a high proportion of apoptotic cells (data not shown). These data suggest that poly $\mathrm{E}$ is less effective than EGCG to induce apoptosis in these cells.

The ability of EGCG to modify cell cycle progression has been reported by many groups (40-42), however, the effect of poly E on the cell cycle is still not clear. In the present study, only the effect of poly E $(50 \mu \mathrm{g} / \mathrm{ml})$ on the cell cycle was evaluated. All cell lines showed a modified cell cycle profile, which was characterized by an accumulation of cells in $\mathrm{G}_{1}$-phase and a decrease of those in S-phase. The same pattern was observed both in immortalized (TCL-1) and cancer (Me180 and HeLa) cells. These results are comparable with the EGCG effect on cell cycle, as reported in the literature. EGCG is known to induce cell cycle arrest at $\mathrm{G}_{0} / \mathrm{G}_{1}$ phase, with a perturbation of expression of cell cycle regulatory genes.

Several cell cycle check-point genes are involved in the regulation of cell growth and apoptosis (42-44). Here, we evaluated the expression of p53, p27 $7^{\mathrm{KIP} 1}$ and $\mathrm{p} 21^{\mathrm{WAF} 1 / \mathrm{Cip} 1}$ proteins on the squamous cervical carcinoma Me180 cells, which were the most sensitive to the lowest concentrations of EGCG. The $\mathrm{p} 53$ and $\mathrm{p} 21^{\mathrm{WAF} 1 / \mathrm{Cip} 1}$ protein expression increased in a dose dependent fashion in the presence of EGCG $(0 ; 5 ; 25$ and $50 \mu \mathrm{g} / \mathrm{ml})$. Similar doseand time-dependent increases have been observed by Gupta et al. (42) The up regulation of p53 by EGCG at low concentrations ( 1 to $5 \mu \mathrm{g} / \mathrm{ml}$ ) has been suggested to induce an arrest of mitosis and DNA damage repair, whereas at higher concentrations $(25-50 \mu \mathrm{g} / \mathrm{ml})$, it may act for induction of apoptosis. Many studies have shown that certain exogenous stimuli may

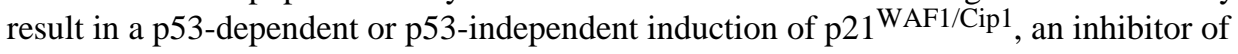
cyclin dependent kinases (cdks) (45-47). This in turn may trigger a series of events such as cell cycle arrest and apoptosis $(44,45)$. Therefore, our data showing an increase of p21 WAF1/Cip1 by EGCG appears p53-dependent in Me180 cancer cell line with wild type of p53.

The effect of the two green tea compounds on the high-risk HPV E7 oncoprotein expression in cervical immortalized and adenocarcinoma cell lines was also evaluated. The E7 protein is one of the early proteins expressed by the viral genome to ensure its reproduction in a differentiated cell. The binding of $\mathrm{E} 7$ to proteins involved in the cell cycle (i.e., pRB, $\mathrm{p} 107 \mathrm{RB}$ ) lead to the degradation of $\mathrm{pRb}$. The release of its transcription factor E2F allows the cell to enter into the $\mathrm{S}$ phase, resulting in uncontrolled cell proliferation (48-51). Our results show a down-regulation of E7 expression by both EGCG and poly E, irrespective of the cancer cell lines. However, the mechanism by which these two green tea polyphenol compounds exert their effects is still unknown. The hypothesis of a down-regulation of E7 by p 27 protein as observed by Lee et al. (52) in HeLa cells is unlikely since the p27 protein level was not affected by EGCG treatment. Therefore, the repression of E7 protein level by p27 might not be a general mechanism. 


\section{Conclusion}

We demonstrate the ability of two green tea polyphenols (EGCG and polyphenol E) to inhibit the proliferation of HPV-immortalized and HPV-positive cancer cells, through cell cycle arrest at the $G_{0} / G_{1}$ phase. Their effects seem dependent on the type of cervical cancer cells (adeno or squamous carcinoma), and poly E was less effective than EGCG on growth inhibition and apoptosis. The cell growth inhibition appears more likely to be mediated via an up regulation of apoptotic-related genes or a down regulation of HPV-E7 oncoprotein, which triggers the phosphorylated retinoblastoma $(\mathrm{pRb})$ and allows the deregulation of cell cycle control. Further studies are required to investigate proteins downstream of p53 activation by green tea polyphenols. We will be able to examine the in vivo effect of green tea compounds on persistent oncogenic HPV infection and low grade (CIN 1) in the context of the currently ongoing chemoprevention trial.

\section{Acknowledgments}

This study was supported in part by the Women's Fund for Health, Education, and Research and the National Institutes of Health, National Cancer Institute grant CA75966 (C.Z.); the National Cancer Institute Consortium contract number N01-CN-35158 (F.G., C.Z., and H.C.); and the Community Clinical Oncology Program Prevention Membership (F.G.) grant number CA101165, CFDA No. 93.395.

\section{References}

1. North, A.; South, C. Cancer Incidence in Antartica (1998-2008). In: Curado, M.; Edwards, B.; HR, S.; Storm, H.; Ferlay, J.; Heanue, M., et al., editors. Cancer Incidence in Five Continents. Lyon: IARC Scientific Publications No. 160; 2007.

2. American Cancer Society. Cancer Facts and Figures 2007. Atlanta: American Cancer Society; 2007.

3. Pisani P, Parkin DM, Ferlay J. Estimates of the worldwide mortality from eighteen major cancers in 1985. Implications for prevention and projections of future burden. Int J Cancer 1993;55(6):891903. [PubMed: 8253525]

4. Alvarez RD, Conner MG, Weiss H, Klug PM, Niwas S, Manne U, et al. The efficacy of 9-cisretinoic acid (aliretinoin) as a chemopreventive agent for cervical dysplasia: results of a randomized double-blind clinical trial. Cancer Epidemiol Biomarkers Prev 2003;12(2):114-119. [PubMed: 12582020]

5. Mitchell MF, Hittelman WK, Lotan R, Nishioka K, Tortolero-Luna G, Richards-Kortum R, et al. Chemoprevention trials and surrogate end point biomarkers in the cervix. Cancer 1995;76(10 Suppl):1956-1977. [PubMed: 8634987]

6. Johnson IT. Phytochemicals and cancer. Proc Nutr Soc 2007;66(2):207-215. [PubMed: 17466103]

7. Lee MJ, Wang ZY, Li H, Chen L, Sun Y, Gobbo S, et al. Analysis of plasma and urinary tea polyphenols in human subjects. Cancer Epidemiol Biomarkers Prev 1995;4(4):393-399. [PubMed: 7655336]

8. Mukhtar H, Ahmad N. Green tea in chemoprevention of cancer. Toxicol Sci 1999;52(2 Suppl):111117. [PubMed: 10630599]

9. Yang CS, Wang ZY. Tea and cancer. J Natl Cancer Inst 1993;85(13):1038-1049. [PubMed: 8515490]

10. Yang GY, Liao J, Kim K, Yurkow EJ, Yang CS. Inhibition of growth and induction of apoptosis in human cancer cell lines by tea polyphenols. Carcinogenesis 1998;19(4):611-616. [PubMed: 9600345]

11. Ahn WS, Huh SW, Bae SM, Lee IP, Lee JM, Namkoong SE, et al. A major constituent of green tea, EGCG, inhibits the growth of a human cervical cancer cell line, CaSki cells, through apoptosis, G(1) arrest, and regulation of gene expression. DNA Cell Biol 2003;22(3):217-224. [PubMed: 12804120]

12. Ahn WS, Yoo J, Huh SW, Kim CK, Lee JM, Namkoong SE, et al. Protective effects of green tea extracts (polyphenon E and EGCG) on human cervical lesions. Eur J Cancer Prev 2003;12(5):383390. [PubMed: 14512803] 
13. Issa AY, Volate SR, Muga SJ, Nitcheva D, Smith T, Wargovich MJ. Green tea selectively targets initial stages of intestinal carcinogenesis in the AOM-ApcMin mouse model. Carcinogenesis 2007;28(9):1978-1984. [PubMed: 17638923]

14. Li WG, Li QH, Tan Z. Epigallocatechin gallate induces telomere fragmentation in HeLa and 293 but not in MRC-5 cells. Life Sci 2005;76(15):1735-1746. [PubMed: 15698852]

15. Yokoyama M, Noguchi M, Nakao Y, Pater A, Iwasaka T. The tea polyphenol, (-)-epigallocatechin gallate effects on growth, apoptosis, and telomerase activity in cervical cell lines. Gynecol Oncol 2004;92(1):197-204. [PubMed: 14751158]

16. Murugan RS, Mohan KV, Uchida K, Hara Y, Prathiba D, Nagini S. Modulatory effects of black tea polyphenols on oxidant-antioxidant profile and expression of proliferation, apoptosis, and angiogenesis-associated proteins in the rat forestomach carcinogenesis model. J Gastroenterol 2007;42(5):352-361. [PubMed: 17530359]

17. Zou C, Vlastos AT, Yang L, Wang J, Nishioka K, Follen M. Effects of difluoromethylornithine on growth inhibition and apoptosis in human cervical epithelial and cancerous cell lines. Gynecol Oncol 2002;85(2):266-273. [PubMed: 11972386]

18. Doll R. An overview of the epidemiological evidence linking diet and cancer. Proc Nutr Soc 1990;49(2):119-131. [PubMed: 2236082]

19. Ames BN, Gold LS. The prevention of cancer. Drug Metab Rev 1998;30(2):201-223. [PubMed: 9606601]

20. Ames BN, Gold LS. The causes and prevention of cancer: the role of environment. Biotherapy 1998;11(2-3):205-220. [PubMed: 9677052]

21. Block G, Patterson B, Subar A. Fruit, vegetables, and cancer prevention: a review of the epidemiological evidence. Nutr Cancer 1992;18(1):1-29. [PubMed: 1408943]

22. Chen D, Daniel KG, Kuhn DJ, Kazi A, Bhuiyan M, Li L, et al. Green tea and tea polyphenols in cancer prevention. Front Biosci 2004;9:2618-2631. [PubMed: 15358585]

23. Katiyar SK, Mukhtar H. Tea antioxidants in cancer chemoprevention. J Cell Biochem Suppl 1997;27:59-67. [PubMed: 9591194]

24. Kohlmeier L, Weterings KG, Steck S, Kok FJ. Tea and cancer prevention: an evaluation of the epidemiologic literature. Nutr Cancer 1997;27(1):1-13. [PubMed: 8970175]

25. Murray, MT. Rev. \& expanded. 2nd ed.. Rocklin, CA: Prima Pub.; 1995. The healing power of herbs: the enlightened person's guide to the wonders of medicinal plants.

26. Lin JK, Liang YC, Lin-Shiau SY. Cancer chemoprevention by tea polyphenols through mitotic signal transduction blockade. Biochem Pharmacol 1999;58(6):911-915. [PubMed: 10509743]

27. Imai K, Nakachi K. Cross sectional study of effects of drinking green tea on cardiovascular and liver diseases. Bmj 1995;310(6981):693-696. [PubMed: 7711535]

28. Imai K, Suga K, Nakachi K. Cancer-preventive effects of drinking green tea among a Japanese population. Prev Med 1997;26(6):769-775. [PubMed: 9388788]

29. Fesus L, Szondy Z, Uray I. Probing the molecular program of apoptosis by cancer chemopreventive agents. J Cell Biochem Suppl 1995;22:151-161. [PubMed: 8538193]

30. Hartwell LH, Kastan MB. Cell cycle control and cancer. Science 1994;266(5192):1821-1828. [PubMed: 7997877]

31. Jiang MC, Yang-Yen HF, Yen JJ, Lin JK. Curcumin induces apoptosis in immortalized NIH 3T3 and malignant cancer cell lines. Nutr Cancer 1996;26(1):111-120. [PubMed: 8844727]

32. Reddy BS, Wang CX, Samaha H, Lubet R, Steele VE, Kelloff GJ, et al. Chemoprevention of colon carcinogenesis by dietary perillyl alcohol. Cancer Res 1997;57(3):420-425. [PubMed: 9012468]

33. Samaha HS, Kelloff GJ, Steele V, Rao CV, Reddy BS. Modulation of apoptosis by sulindac, curcumin, phenylethyl-3-methylcaffeate, and 6-phenylhexyl isothiocyanate: apoptotic index as a biomarker in colon cancer chemoprevention and promotion. Cancer Res 1997;57(7):1301-1305. [PubMed: 9102217]

34. Yang CS, Chen L, Lee MJ, Balentine D, Kuo MC, Schantz SP. Blood and urine levels of tea catechins after ingestion of different amounts of green tea by human volunteers. Cancer Epidemiol Biomarkers Prev 1998;7(4):351-354. [PubMed: 9568793] 
35. Yamamoto T, Hsu S, Lewis J, Wataha J, Dickinson D, Singh B, et al. Green tea polyphenol causes differential oxidative environments in tumor versus normal epithelial cells. J Pharmacol Exp Ther 2003;307(1):230-236. [PubMed: 12954803]

36. Karlseder J, Broccoli D, Dai Y, Hardy S, de Lange T. p53- and ATM-dependent apoptosis induced by telomeres lacking TRF2. Science 1999;283(5406):1321-1325. [PubMed: 10037601]

37. Multani AS, Ozen M, Narayan S, Kumar V, Chandra J, McConkey DJ, et al. Caspase-dependent apoptosis induced by telomere cleavage and TRF2 loss. Neoplasia 2000;2(4):339-345. [PubMed: 11005568]

38. Ramirez R, Carracedo J, Jimenez R, Canela A, Herrera E, Aljama P, et al. Massive telomere loss is an early event of DNA damage-induced apoptosis. J Biol Chem 2003;278(2):836-842. [PubMed: 12409303]

39. Noguchi M, Yokoyama M, Watanabe S, Uchiyama M, Nakao Y, Hara K, et al. Inhibitory effect of the tea polyphenol, (-)-epigallocatechin gallate, on growth of cervical adenocarcinoma cell lines. Cancer Lett 2006;234(2):135-142. [PubMed: 15907368]

40. Ahmad N, Cheng P, Mukhtar H. Cell cycle dysregulation by green tea polyphenol epigallocatechin-3-gallate. Biochem Biophys Res Commun 2000;275(2):328-334. [PubMed: 10964666]

41. Gupta S, Ahmad N, Nieminen AL, Mukhtar H. Growth inhibition, cell-cycle dysregulation, and induction of apoptosis by green tea constituent (-)-epigallocatechin-3-gallate in androgen-sensitive and androgen-insensitive human prostate carcinoma cells. Toxicol Appl Pharmacol 2000;164(1): 82-90. [PubMed: 10739747]

42. Gupta S, Hussain T, Mukhtar H. Molecular pathway for (-)-epigallocatechin-3-gallate-induced cell cycle arrest and apoptosis of human prostate carcinoma cells. Arch Biochem Biophys 2003;410(1):177-185. [PubMed: 12559991]

43. Schoelch ML, Regezi JA, Dekker NP, Ng IO, McMillan A, Ziober BL, et al. Cell cycle proteins and the development of oral squamous cell carcinoma. Oral Oncol 1999;35(3):333-342. [PubMed: 10621856]

44. Scully C, Field JK, Tanzawa H. Genetic aberrations in oral or head and neck squamous cell carcinoma (SCCHN): 1. Carcinogen metabolism, DNA repair and cell cycle control. Oral Oncol 2000;36(3):256-263. [PubMed: 10793327]

45. Gartel AL, Serfas MS, Tyner AL. p21--negative regulator of the cell cycle. Proc Soc Exp Biol Med 1996;213(2):138-149. [PubMed: 8931660]

46. Ortega S, Malumbres M, Barbacid M. Cyclin D-dependent kinases, INK4 inhibitors and cancer. Biochim Biophys Acta 2002;1602(1):73-87. [PubMed: 11960696]

47. Pavletich NP. Mechanisms of cyclin-dependent kinase regulation: structures of Cdks, their cyclin activators, and Cip and INK4 inhibitors. J Mol Biol 1999;287(5):821-828. [PubMed: 10222191]

48. Davies R, Hicks R, Crook T, Morris J, Vousden K. Human papillomavirus type 16 E7 associates with a histone $\mathrm{H} 1$ kinase and with p107 through sequences necessary for transformation. J Virol 1993;67(5):2521-2528. [PubMed: 8386265]

49. Dyson N, Howley PM, Munger K, Harlow E. The human papilloma virus-16 E7 oncoprotein is able to bind to the retinoblastoma gene product. Science 1989;243(4893):934-937. [PubMed: 2537532]

50. Watanabe S, Sato H, Komiyama N, Kanda T, Yoshiike K. The E7 functions of human papillomaviruses in rat 3Y1 cells. Virology 1992;187(1):107-114. [PubMed: 1310552]

51. Zerfass K, Schulze A, Spitkovsky D, Friedman V, Henglein B, Jansen-Durr P. Sequential activation of cyclin $\mathrm{E}$ and cyclin A gene expression by human papillomavirus type $16 \mathrm{E} 7$ through sequences necessary for transformation. J Virol 1995;69(10):6389-6399. [PubMed: 7666540]

52. Lee SH, Kim JW, Oh SH, Kim YJ, Rho SB, Park K, et al. IFN-gamma/IRF-1-induced p27kip1 down-regulates telomerase activity and human telomerase reverse transcriptase expression in human cervical cancer. FEBS Lett 2005;579(5):1027-1033. [PubMed: 15710386] 

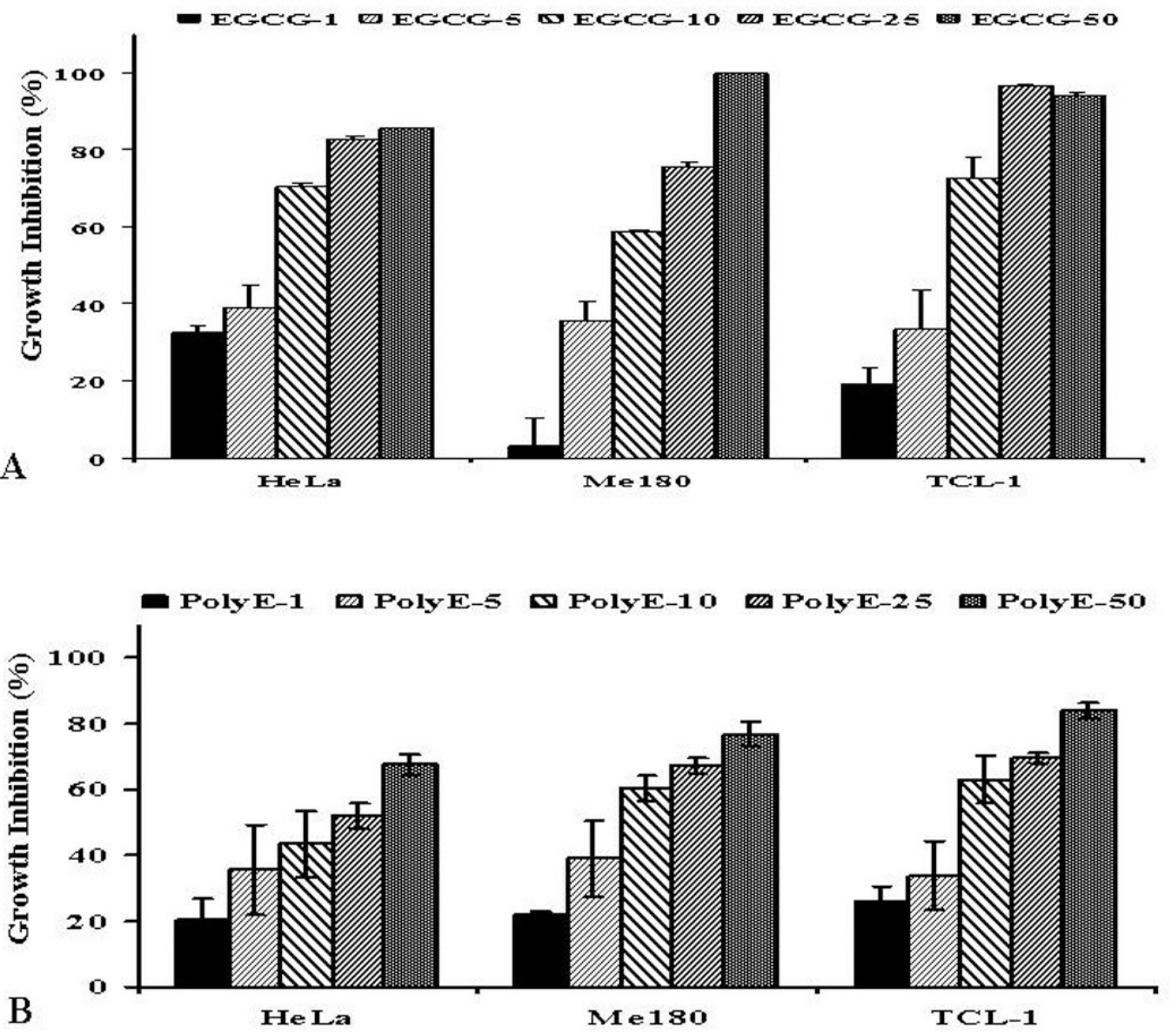

Fig. 1.

Effect of green tea compound on the growth of cervical epithelial cell line TCL1 and cervical cancer cell lines HeLa and Me180. Cells were treated with either EGCG (upper panel) or poly E (lower panel) at concentrations of $0,1,5,10,25$, and $50 \mu \mathrm{g} / \mathrm{ml}$ for 5 days. Cells without any treatment were used as a control. The percentage of growth inhibition was calculated, as described in Materials and Methods. Cells were fixed and stained with crystal violet to measure the cell viability. The data was presented as the mean \pm standard derivation of triplicate determinations. 


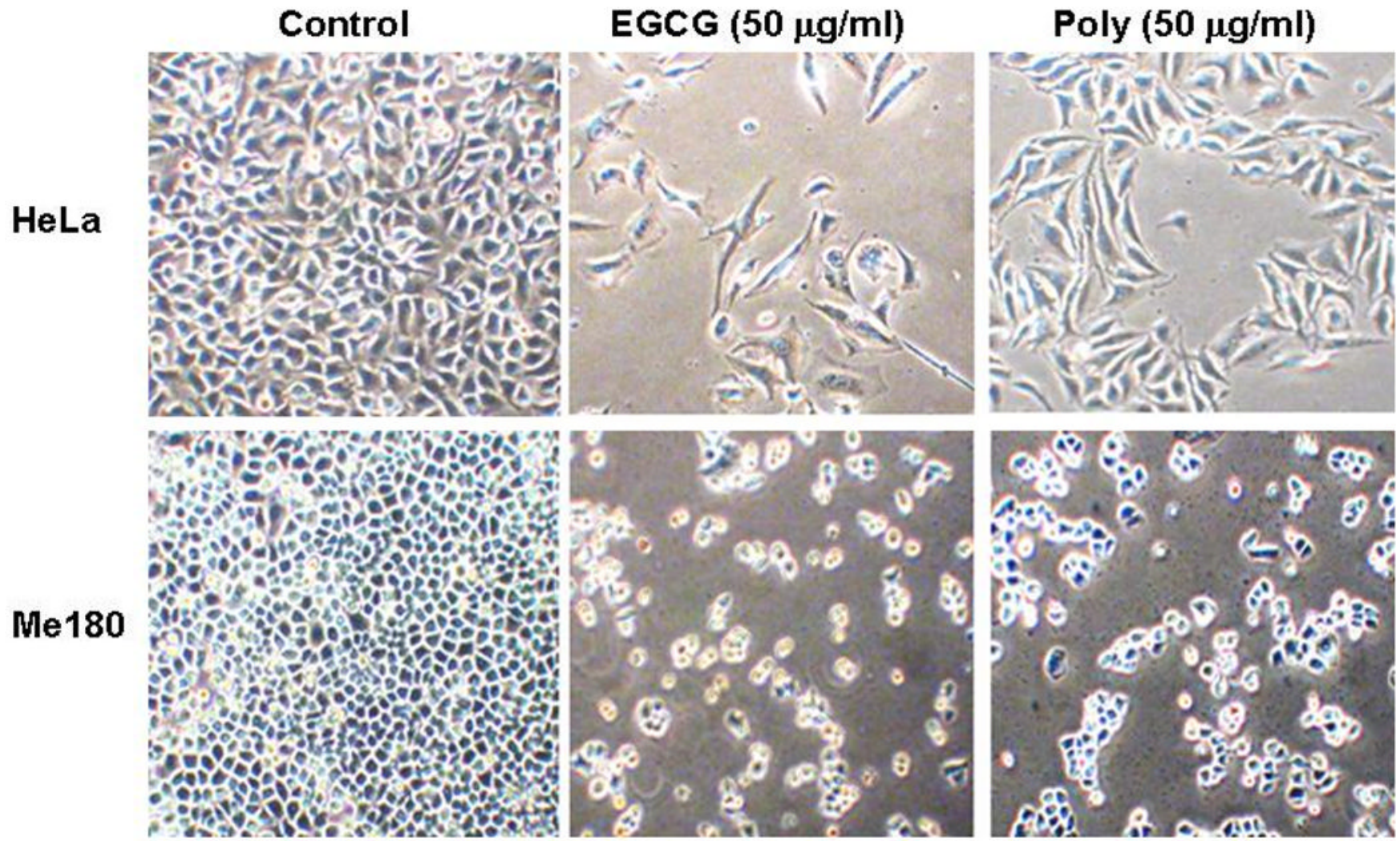

Fig. 2.

Representative morphologic changes induced by EGCG or poly E at $50 \mu \mathrm{g} / \mathrm{ml}$ in cervical cancer cell lines Hela and Me180. 


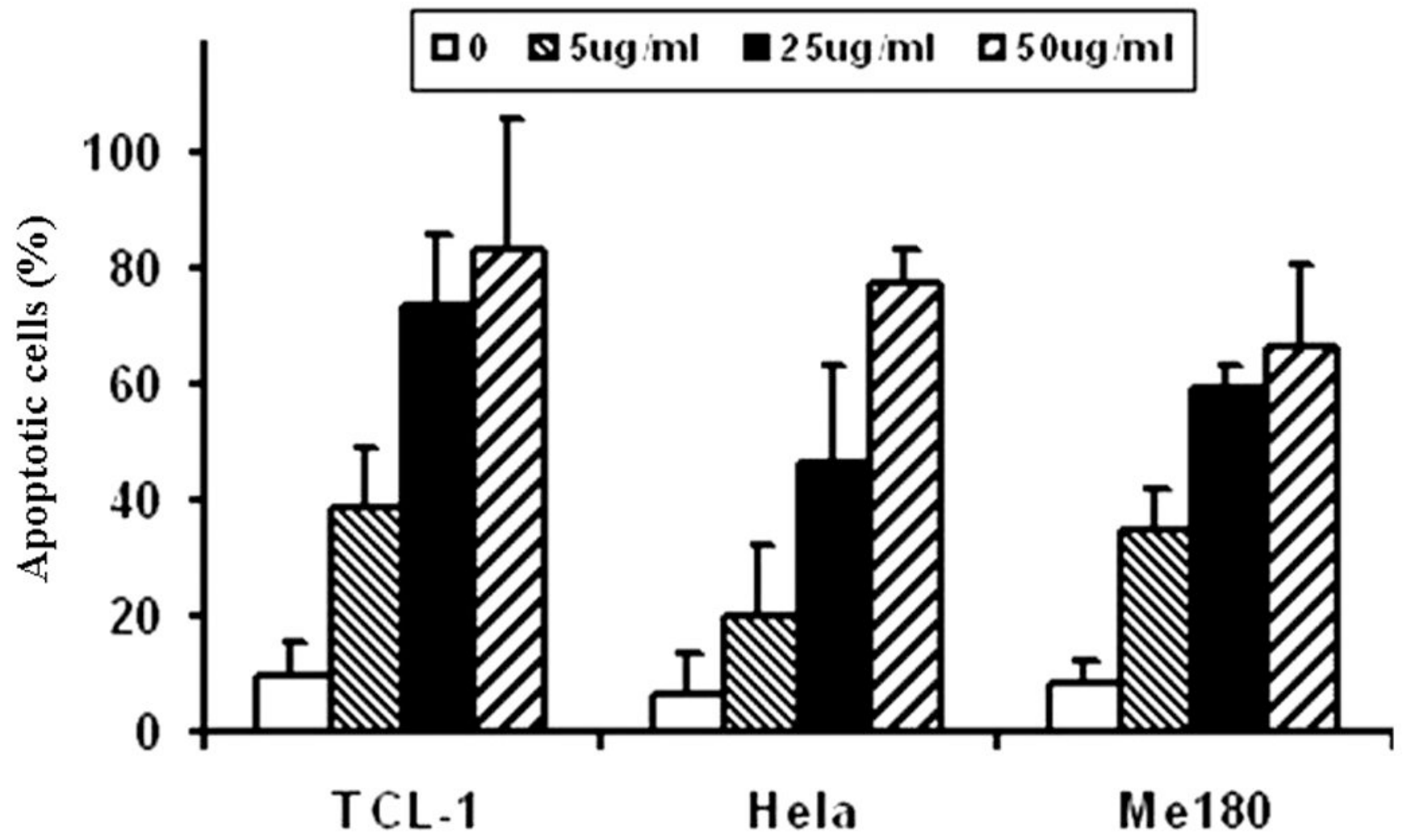

Fig. 3.

Effect of EGCG on apoptosis induction in TCL-1, HeLa, and Me180 cells. Cells were treated with $50 \mu \mathrm{g} / \mathrm{ml}$ of EGCG for 5 days. The cells were stained with fluorescein-labeled dUTP to label DNA fragments by the TUNEL method. The percentage of apoptosis cell population showed in histogram. 
Actin

Fig. 4.

Representative effect of EGCG on p53, p21, and p27 protein levels in cervical cancer me180 cells. Proteins were extracted from cells treated with 5, 25, $50 \mu \mathrm{g} / \mathrm{ml}$ for 3 days. Thirty micrograms of proteins per lane was subjected to SDS-PAGE (polyacrylamide gel electrophoresis). The p53, p21 and p27 proteins were identified by blotting with monoclonal antibodies. Immunoreactive bands were visualized using an enhanced chemiluminescence method (see Materials and Methods). The blots were stripped and then re-blotted to mouse anti- $\beta$-actin antibody for assessment of loading in each lane. 


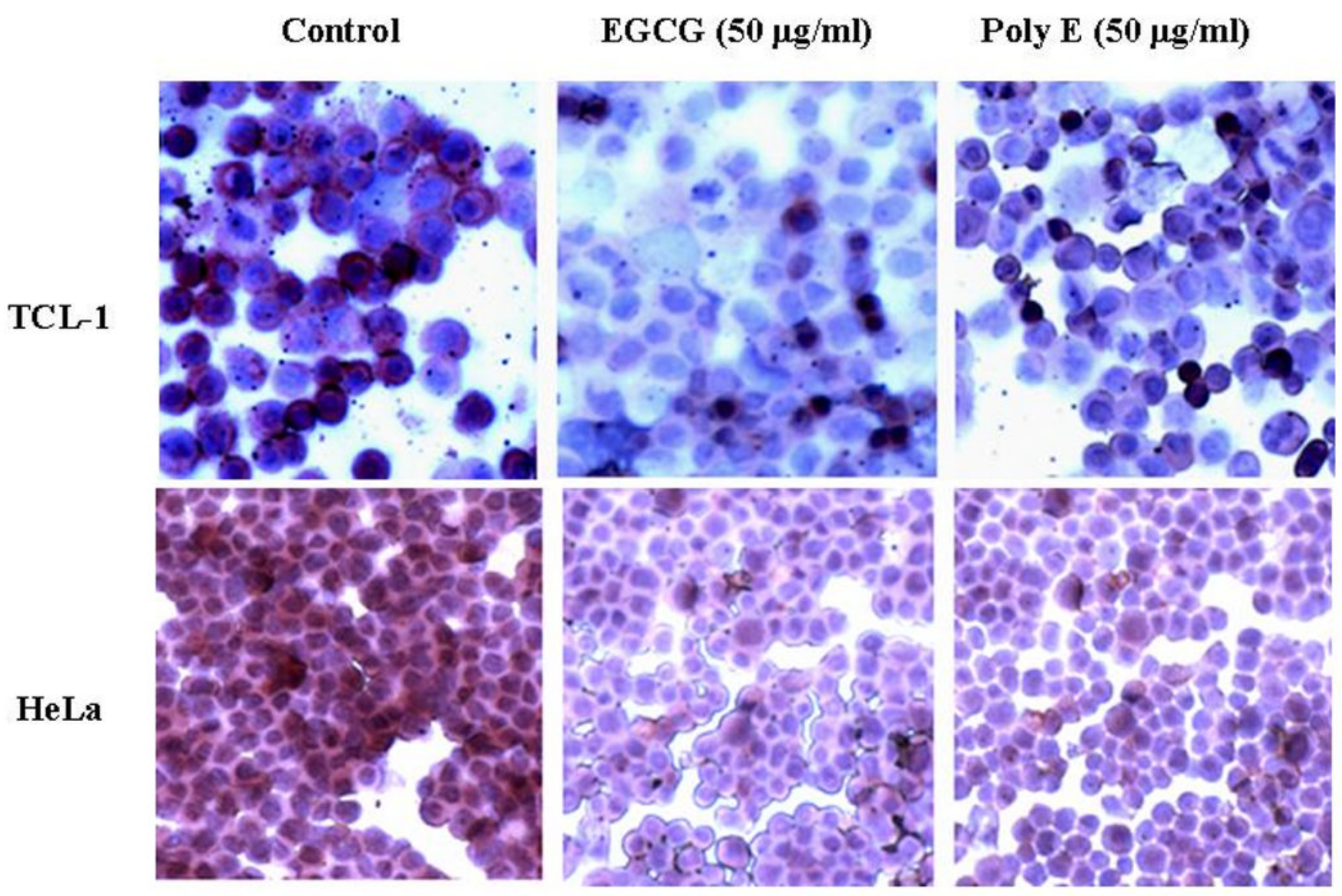

Fig. 5.

Representative immunohistochemistry staining of HPV-E7 in cervical cells treated with green tea compound. The expression of HPV-E-7 in TCL1 and HeLa cells treated with 0 or $50 \mu \mathrm{g} / \mathrm{ml}$ EGCG or poly E were stained by immunohistochemistry. 